\title{
LABORATORIJSKO MJERENJE PARAMETARA TOKA PRI POJAVI HIDRAULIČKIH \\ TRANZIJENATA
}

\author{
LABORATORY MEASUREMENT OF FLOW \\ PARAMETERS DUE TO APPEARANCE OF \\ HYDRAULIC TRANSIENTS
}

\author{
Mateo Brenko*, Elvis Žic*, Lara Đuričanin*
}

\begin{abstract}
Sažetak
U radu je dan opis pojave oscilacija vodnih masa na sustavu akumulacija - dovodni cjevovod - vodna komora, kao i opis pojave hidrauličkog udara koja nastaje uslijed naglog zatvaranja zatvarača na danom sustavu. U svrhu dobivanja mjerodavne hidrodinamičke analize oscilacija vodnih masa u cilindričnoj vodnoj komori provedena su eksperimentalna mjerenja na fizikalnom modelu GUNT HM156 koji predstavlja sastavni dio mjernog instrumentarija hidrotehničkog laboratorija Građevinskog fakulteta Sveučilišta u Rijeci. Hidrodinamička analiza je provedena na temelju više eksperimentalnih pokusa u kojima su kao ulazne vrijednosti uzete promjenjiva razina gornje vode u akumulaciji te različiti dotok vode (protok) u cilindričnu vodnu komoru koji je reguliran putem kuglastog ventila. Hidrodinamička analiza se bazira na dva odvojena dijela. U prvom dijelu je razmatrana isključivo promjena oscilacija vodnih masa u vodnoj komori kod naglog zatvaranja solenoidnog ventila, dok je drugi dio analize vezan za pojavu hidrauličkog udara i definiranje brzine širenja tlačnih poremećaja u vodi. Za potrebe istraživanja na fizikalnom modelu korištena je sofisticirana mjerna tehnika kao i primjena osciloskopa.
\end{abstract}

Ključne riječi: oscilacije vodne mase, hidraulički udar, cilindrična vodna komora, brzina zvuka, fizikalni model, hidraulička analiza

\begin{abstract}
This paper presents a description of the water mass oscillation on the accumulation system - inlet pipe - water chamber, as well as a description of the occurrence of a
\end{abstract}

\footnotetext{
* Sveučilište u Rijeci, Građevinski fakultet, Radmile Matejčić 3, 51000 Rijeka E-mail: elvis.zic@uniri.hr; \{mateo.brenko,lara.duricanin\}@student.uniri.hr
} 
water hammer due to the sudden closure of the shutter on a given system. For the purpose of obtaining the relevant hydrodynamic analysis of the water mass oscillation in the cylindrical water chamber, experimental measurements were carried out on the physical model GUNT HM156, which is an integral part of the measuring instrument of the hydro technical laboratory of the Faculty of Civil Engineering of the University of Rijeka. The hydrodynamic analysis was carried out based on more experimental trials, in which the input water values were the changeable upper water level in the accumulation and the different water influx (flow) in the cylindrical water chamber regulated by the ball valve. The hydrodynamic analysis is based on two separate parts. In the first part, only the water mass oscillation in the water chamber at the sudden closing of the solenoid valve has been considered, while the second part of the analysis is related to the occurrence of a water hammer, and the defining of the velocity propagation of pressure disorders in the water. For the purposes of the research on the physical model, sophisticated measurement technique as well as the oscilloscope were used.

Key words: water mass oscillation, water hammer, cylindrical water chamber, sound velocity, physical model, hydraulic analysis

\section{Osnove hidrauličkih tranzijenta}

U radu je dokumentirana laboratorijska analiza oscilacija vodnih masa i pojave hidrauličkog udara u sustavu pod tlakom. Takve pojave nazivamo hidraulički tranzijenti i oni nastaju prilikom promjene brzine gibanja vode u tlačnim sustavima. Kao primjer nestacionarnog gibanja pod tlakom mogu se uzeti gibanja koja nastaju u dovodnom tunelu kod visokotlačnih hidroelektrana prilikom mijenjanja rada režima turbina, odnosno kada se one zaustavljaju ili puštaju u pogon. U ovome radu istraženi su sustavi pod tlakom u kojima su u obzir uzeta i elastična svojstva vode i stijenki cijevi. Zbog takvoga naglog zaustavljanja turbine nastaju značajne promjene tlaka, što dovodi do pojave hidrauličkog udara.

Vodne komore su objekti koji se grade neposredno prije turbine gdje voda ulazi u pogon. Njihova svrha je da se umanji neželjeno djelovanje tromosti vode, kao i izbjegavanje efekta koji nastaju zbog njene stišljivosti. Osnovna zadaća vodne komore je osiguravanje dovoljne količine vode prilikom pokretanja turbine kako bi se osigurao dotok vode prije nego što on dotječe u dovoljnoj količini iz dovodnog tunela te prihvaćanje dijela vode iz dovodnog tunela prilikom zaustavljanja turbine. Na taj se način izbjegava nagla promjena brzine vode te umanjuje nepoželjni efekti pojava hidrauličkog udara $[1,2]$. Vodne komore spadaju u hidrotehničke objekte čija je izgradnja složena i skupa. Postoji nekoliko osnovnih tipova vodnih komora (cilindrična vodna komora, vodna komora s gornjim proširenjem, raščlanjena vodna komora, vodna komora s prigušivačem, diferencijalna ili Johnsonova vodna komora, vodna komora na Venturi prolazu, vodna komora sa zračnim prigušivačem te dvojna vodna komora) koje su 
osmišljene da zadovoljavaju kriterij stabilnosti uz najmanja ulaganja ovisno o potrebi. Detaljan prikaz i značajke vodnih komora dane su u radu [1].

Kad turbina u sustavu akumulacija - dovodni tunel - vodna komora radi $\mathrm{u}$ jednolikom režimu, razina vode u vodnoj komori (V.K.) predstavlja visinu piezometarske linije. Promjena režima toka se najprije očituje u tlačnom cjevovodu gdje se javlja hidraulički udar. Kad se turbina pokrene, vodna se komora prazni i smanjuje se tlak na kraju dovodnog tunela te se voda u cijevi počinje kretati. Voda u dovodnom tunelu ubrzava toliko da protok u dovodnom tunelu bude veći od protoka u tlačnoj cijevi. Tada razina vode u vodnoj komori raste, a tlak i protok na kraju dovodnog tunela se smanjuju. Tako se uspostavlja oscilacija vodnih masa na sustavu akumulacija dovodni tunel - vodna komora. Prilikom hidrauličkog proračuna određuje se najniža kota u vodnoj komori kako ne bi došlo do uvlačenja zraka u dovodni tunel i tlačnu cijev prema turbini. Amplituda koja predstavlja maksimalni porast razine vode može se smanjiti povećavanjem poprečnog presjeka vodne komore ugradnjom raznih tipova vodnih komora [2].

Važno je naglasiti da proces oscilacije vodnih masa i hidraulički udar nisu vezani događaji iako imaju isto ishodište tj. manevriranje zasuna. Naime, oscilacije vodnih masa se odvijaju kroz duži vremenski period, dok hidraulički udar traje mnogo kraće. Najčešće, pokretanje vode u vodnoj komori započne onda kada je hidraulički udar već prošao više puta kroz sustav. Upravo iz tog razloga se mogu konstruirati različiti matematički modeli za jednu i drugu pojavu, a da sami modeli nisu vezani jedan na drugi. Napredne simulacije uključuju u numeričke modele i refleksiju hidrauličkog udara (koja nije potpuna) pa se dodaje i dio transmisije tlačnog vala u dovodni tunel.

\section{Teorijske osnove oscilacija vodenih masa}

Proračun oscilacija vode u vodnoj komori zasniva se na Bernoullijevoj jednadžbi (B.J.) u nestacionarnom obliku (1) koja glasi, [3, 4, 5] (Slika 1.):

$$
z_{1}+\frac{P_{1}}{\rho g}+\frac{\alpha v_{1}^{2}}{2 g}=z_{2}+\frac{P_{2}}{\rho g}+\frac{\alpha v_{2}^{2}}{2 g}+\Delta H_{e}+\frac{1}{g} \int_{l 1}^{l 2} \frac{\partial v}{\partial t} d l
$$

Pojedine fizikalne veličine u gornjem izrazu su: geodetska visina $z[\mathrm{~m}]$, tlak $p[\mathrm{~Pa}]$, srednja brzina mjerena po osi cijevi $v[\mathrm{~m} / \mathrm{s}], \Delta H_{e}$ koja predstavlja zbroj svih lokalnih i linijskih gubitaka energetske visine između dva profila $\mathrm{u}[\mathrm{m}]$, dok izraz $\frac{1}{g} \int_{l 1}^{l 2} \frac{\partial v}{\partial t} d l$ definira integralnu veličinu energetske visine između dva presjeka potrebne za promjene brzine vode, [m]. Posljednji član pod integralom sadrži promjenu brzine u vremenu uzduž toka. 


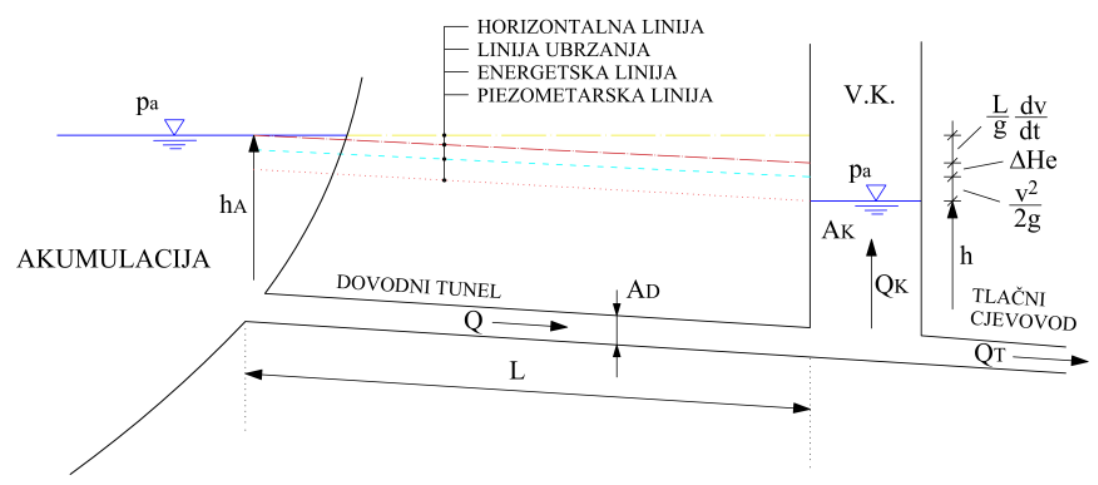

Slika 1. Prikaz karakterističnih veličina u Bernoullijevoj jednadžbi [3]

Usvaja se da nema zakašnjenja u promjeni brzine u dovodnom tunelu, član $\frac{\partial v}{\partial t}$ nije ovisan o stacionaži pa se B.J. može napisati u obliku $[3,4]$ :

$$
z_{1}+\frac{P_{1}}{\rho g}+\frac{\alpha v_{1}^{2}}{2 g}=z_{2}+\frac{P_{2}}{\rho g}+\frac{\alpha v_{2}^{2}}{2 g}+\Delta H_{e}+\frac{L}{g} \frac{d v}{d t}
$$

gdje je $L$ duljina između dva profila po osi cijevi. Kako je brzina u akumulaciji zanemarivo malena, B.J. poprima oblik [3]:

$$
h_{A}=h \pm \beta v^{2}+\frac{L}{g} \frac{d v}{d t}
$$

gdje su $h_{A}$ vodostaj u akumulaciji [m n.m.], $h$ razina vode u vodnoj komori [m n.m.], $\frac{L}{g} \frac{d v}{d t}$ član koji predstavlja ubrzanje mase vode u dovodnom tunelu koji je pozitivan u slučaju ubrzanja te $\beta v^{2}$ ukupni gubici koji imaju pozitivan predznak ako brzina ima smjer prema vodnoj komori. Gubici se određuju prema sljedećoj formulaciji $[3,6]$ :

$$
\Delta H_{e}=\beta v^{2}=\left(\xi_{U L}+\lambda \frac{L}{D}+\xi_{I Z}\right) \frac{v^{2}}{2 g}
$$

pri čemu su $\xi_{U L}$ i $\xi_{I Z}$ lokalni koeficijenti gubitka na ulazu i izlazu iz dovodnog tunela, dok je $\lambda$ linijski koeficijent gubitaka. Jednadžba kontinuiteta glasi [3]:

$$
Q-Q_{T}= \pm A_{K} \frac{d h}{d t}=Q_{K}
$$

pri čemu su $Q=A_{D} v$ protok u dovodnom tunelu $\left[\mathrm{m}^{3} / \mathrm{s}\right], A_{D}$ površina poprečnog presjeka dovodnog tunela $\left[\mathrm{m}^{2}\right], Q_{T}$ protok u tlačnoj cijevi $\left[\mathrm{m}^{3} / \mathrm{s}\right]$, $Q_{K}=A_{K} \frac{d h}{d t}$ protok kojim se puni vodna komora $\left[\mathrm{m}^{3} / \mathrm{s}\right], A_{K}$ površina poprečnog presjeka cilindrične vodne komore $\left[\mathrm{m}^{2}\right]$, te $\frac{d h}{d t}$ brzina rasta vodostaja u vodnoj komori $(\dot{h})[\mathrm{m} / \mathrm{s}]$. Razlika protoka u dovodnom tunelu i tlačnoj cijevi ulazi ili izlazi iz vodne komore. Za izvod jednadžbe oscilacija u 
vodnoj komori koristit će se slučaj trenutnog zatvaranja dovoda do turbina, pri čemu se usvajaju sljedeće pretpostavke, [7, 8]:

1) dovodni tunel je dugačak objekt i ima dominantan utjecaj trenja, a ti gubici su jednaki u nestacionarnom režimu kao u stacionarnom pri istoj brzini $v$

2) vrijedi Darcy-Weisbachov zakon otpora trenja [3]:

za glatke cijevi: $\frac{1}{\sqrt{\lambda}}=2 \log \left(\frac{\operatorname{Re} \sqrt{\lambda}}{2.51}\right)$

za prijelazno područje (Colbrook): $\frac{1}{\sqrt{\lambda}}=-2 \log \left(\frac{2.51}{R e \sqrt{\lambda}}+\frac{k}{3.71 D}\right)$

za hidraulički hrapave cijevi: $\frac{1}{\sqrt{\lambda}}=-2 \log \left(\frac{3.71 D}{k}\right)$

3) inercija vode u vodnoj komori se zanemaruje.

Novi oblik jednadžbe kontinuiteta poprima oblik:

$$
Q=A_{K} \frac{d h}{d t}
$$

Ukoliko se brzina vode izrazi u obliku:

$$
v=\frac{A_{K}}{A_{D}} \frac{d h}{d t}
$$

diferenciranjem izraza (8) dobiva se izraz za promjenu brzine:

$$
\frac{d v}{d t}=\frac{A_{K}}{A_{D}} \frac{d^{2} h}{d t^{2}}
$$

Bernoullijeva jednadžba se može napisati u sljedećem obliku:

$$
\frac{L}{g} \frac{d v}{d t}+\left(h-h_{A}\right) \pm \beta v^{2}=0
$$

Kada se uvrsti izraz (9) u (10) dobiva se jednadžba [3, 9]:

$$
\frac{L A_{K}}{g A_{D}} \frac{d^{2} h}{d t^{2}}+\left(h-h_{A}\right) \pm \beta v^{2}=0
$$

Budući da se jednadžba (11) ne može općenito riješiti, rješenje se dobiva numeričkim ili grafičkim postupcima ili se pojednostavljuje, [3]. Da bi se odredile vrijednosti rješenja iz jednadžbe (11), u ovom će se slučaju zanemariti utjecaj trenja, tj. vrijedi $\pm \beta v^{2}=0$. Također, uvest će se oznaka $z=h-h_{A}$ jer se oscilacije u vodnoj komori mjere u odnosu na akumulaciju pa će jednadžba (11) imati sljedeći oblik:

$$
\frac{L A_{K}}{g A_{D}} \frac{d^{2} h}{d t^{2}}+z=0
$$

Rješenje ove linearne homogene diferencijalne jednadžbe glasi [3]:

$$
z=c_{1} \cos \left(\sqrt{\frac{g A_{D}}{L A_{K}} * t}\right)+c_{2} \sin \left(\sqrt{\frac{g A_{D}}{L A_{K}} * t}\right)
$$


Vrijednost $c_{1}$ slijedi iz početnog uvjeta $t=0 i z=0$, tj. u vremenu kada oscilacije nisu još započele. Uvođenjem tog uvjeta rezultira da je $c_{1}=0$. Vrijednost $c_{2}$ se dobije iz uvjeta da je porast razine vode određen protokom $\mathrm{u}$ dovodnom tunelu prije početka smanjenja protoka, tj. $\frac{d z}{d t}=v_{0} \frac{A_{D}}{A_{K}} \mathrm{i}$ on iznosi $c_{2}=v_{0} \sqrt{\frac{L A_{D}}{g A_{K}}}$. Tada jednadžba (13) poprima sljedeći oblik:

$$
z=v_{0} \sqrt{\frac{L A_{D}}{g A_{K}}} \sin \left(\sqrt{\frac{g A_{D}}{L A_{K}} * t}\right)
$$

Rješenje prikazuje da su oscilacije u obliku sinusne funkcije, a pojedini izrazi definiraju:

$$
\begin{array}{ll}
z_{\text {max }}=v_{0} \sqrt{\frac{L A_{D}}{g A_{K}}} & \text { maksimalnu oscilaciju koja se pojavljuje u } \\
& \text { vremenu } t=\frac{T}{4},[\mathrm{~m}] \\
T=2 \pi v_{0} \sqrt{\frac{L A_{K}}{g A_{D}}} & \text { period oscilacija, }[\mathrm{s}] \\
v=v_{0} \cos \left(\frac{2 \pi}{T} * t\right) & \text { oscilacije brzine, }[\mathrm{m} / \mathrm{s}] \\
v_{0} & \text { brzina vode u dovodnom tunelu, }[\mathrm{m} / \mathrm{s}] .
\end{array}
$$

Kada se gubici aproksimiraju pravcem i kada se energetska jednadžba (14) integrira, dobiva se jednadžba maksimalne oscilacije [3]:

$$
z_{\max }=\left(1-\frac{\pi}{8}\right) \Delta h_{0}-\sqrt{\left(\frac{\pi \Delta h_{0}}{8}\right)^{2}+\frac{L A_{D}}{g A_{K}} v_{0}^{2}}
$$

Kad se hidroelektrana pusti u pogon, ona proizvodi struju određene frekvencije, a budući da ta frekvencija treba biti konstantna jer elektroenergetski sustav ne trpi promjene, ugrađuje se regulator protoka. Da bi frekvencija bila konstantna, kutna brzina okretaja rotora generatora mora biti konstantna što znači da moment vanjskih sila mora biti jednak momentu otpora [3]. Regulator protoka prilagođava protok $Q$ kako bi snaga ostala konstantna. Vodna komora se mora dimenzionirati tako da oscilacije budu što stabilnije. Stabilnost vodne komore se ispituje u najnepovoljnijoj varijanti, tj. kad je kota vode $\mathrm{u}$ akumulaciji najniža, a kota razine vode $\mathrm{u}$ vodnoj komori najviša, [3, 4]. Cilindrična vodna komora je stabilna (prema D. Thomi) kada joj tlocrtna površina ispunjava uvjet $[3,9]$ :

$$
A_{K} \geq \frac{v_{0}^{2}}{2 g} \frac{L A_{D}}{\Delta h_{0}\left(H_{S t}-\Delta h_{0}\right)}
$$

Izraz (16) se usvaja samo kada vrijedi nejednakost [3]:

$$
\frac{L}{g} \frac{A_{D}}{A_{k}} \frac{v_{0}^{2}}{\Delta h_{0}^{2}} \geq 40
$$


pri čemu je $A_{K}$ poprečni presjek cilindrične vodne komore $\left[\mathrm{m}^{2}\right]$, a $A_{D}$ poprečni presjek dovodnog tunela, $\left[\mathrm{m}^{2}\right]$.

\subsection{Fizikalni model HM 156}

Fizikalni model HM 156 napravljen je za potrebe mjerenja određenih fizikalnih veličina kod pojave hidrauličkog udara i oscilacija vodnih masa u cilindričnoj vodnoj komori. Za korištenje eksperimentalnog fizikalnog modela HM 156 potrebno je imati i baznu stanicu HM 150 za recirkuliranje vode u sustavu (Slika 2.). Voda se iz spremnika pumpa ka modulu HM 150 preko cijevi za dovod. Spremnik se nalazi na metalnom postolju. Opremljen je preljevom koji ulazi u povratnu cijev. Ugrađen je indikator razine za provjeru razine vode u spremniku. Voda izlazi iz spremnika kroz dvije cijevi. Jedna cijev služi za modeliranje pojave hidrauličkog udara, dok druga služi za modeliranje oscilacija vodnih masa u cilindričnoj vodnoj komori. Solenoidni ventil V1 (mehanički jednostavan elektromagnetski uređaj koji pretvara električnu energiju izravno u linearno kretanje - to je elektromagnetski ventil koji kontrolira elektromagnetski prekidač; uglavnom je ili normalno otvoren ili normalno zatvoren) ugrađen je u dio cijevi u kojem se generira i propagira hidraulički udar (Slika 3.). Senzori za tlak PI1 i PI2 su ugrađeni u cijevi na $3 \mathrm{~m}$ međusobnog razmaka (Slika 2.). Hidraulički udar nastaje kada se ručno zatvori ventil V3, a njega detektira senzor tlaka PI3 (Slika 3.). Postoje dva prigušujuća ventila (V2 i V4) koji se nalaze na kraju svakog dijela cijevi, a služe za zatvaranje dijela cijevi koji se u određenim situacijama ne koriste u eksperimentu (Slika 3.). Vrijednosti tlaka izmjerene senzorima tlaka prikazuju se u posebnom programu na osciloskopu.

Na prednjoj strani upravljačke jedinice nalaze se priključci i upravljački elementi (Slika 4.): 4 BNC utičnice (utičnice za senzor tlaka PI1, PI2 i PI3), signali okidača koji se mogu spojiti na osciloskop (elektromagnetski ventil V1; preporuka je da ventil bude zatvoren oko 3 sekunde), prekidač za napajanje. Stražnja strana upravljačke jedinice ima priključke za napajanje uređaja i komponenti kao što su: USB priključak za računalo, konektori za 3 senzora tlaka, priključak za solenoidni ventil V1 te glavni strujni adapter.

Na računalu koji se koristi uz ovaj fizikalni model instalira se računalni program za vizualizaciju histograma pojedine fizikalne veličine. Unutar programa se može definirati eksperiment sa hidrauličkim udarom ili eksperiment s oscilacijama vodene mase u cilindričnoj vodnoj komori. Prije pokretanja bazne stanice treba sprovesti određene korake koje treba slijediti, a oni su detaljno opisani u radu [1]. Spremnik koji se nalazi na dnu fizikalnog modela HM156 napuni se vodom do približno $10 \mathrm{~cm}$ ispod gornjeg ruba spremnika te se nakon uključivanja pumpe otvaraju ventili za recirkulaciju vode u sustav (Slika 2.). Nakon toga se pokreće fizikalni model 
HM 156 te se spaja na računalo pomoću USB kabela. Na stražnjoj strani osciloskopa se priključuju senzori pritiska PI1, PI2, PI3 te soleonidni ventil V1 (Slika 4.).

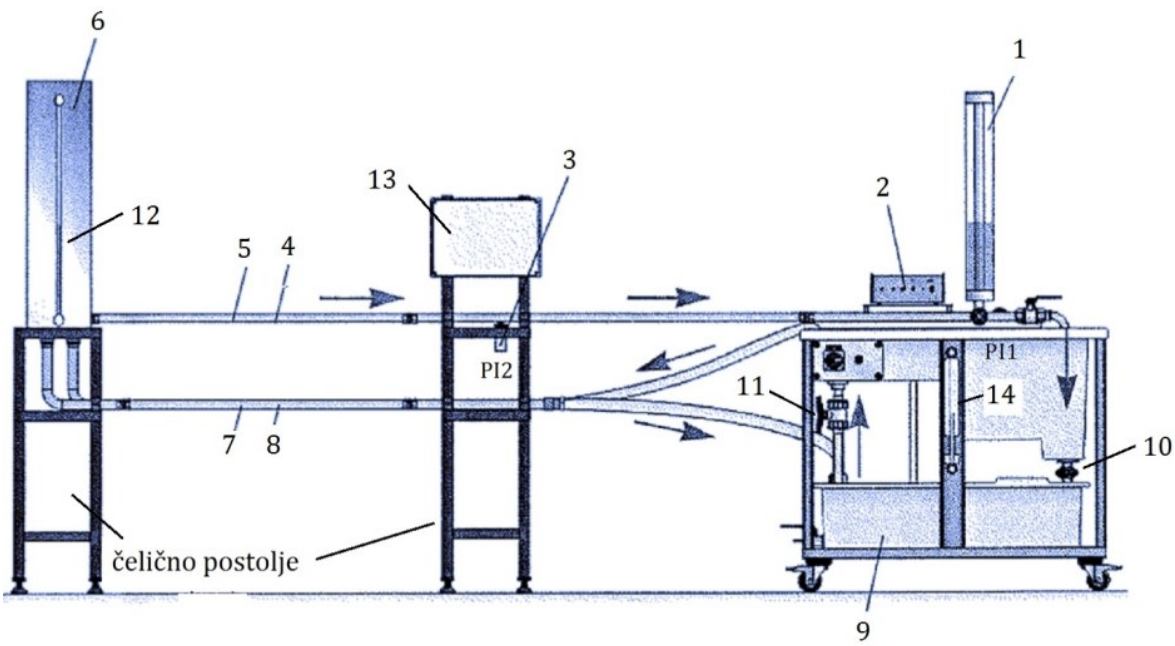

Slika 2. Shematski prikaz uređaja HM150 i HM156 [8]

1 - cilindrična vodna komora, 2 - kontrolna baza, 3 - senzor pritiska PI2, 4 - eksperimentalni dio cijevi za vodnu komoru, 5 - eksperimentalni dio cijevi za hidraulički udar, 6 - spremnik vode, 7 - dovodna cijev, 8 - odvodna cijev, 9 - HM150 bazni modul (spremnik vode sa ugrađenom pumpom za recirkulaciju vode), 10 - ventil za zatvaranje i volumetrijsko mjerenje protoka, 11 - prigušni ventil, 12 - skala za prikaz razine vode u spremniku, 13 - prikaz fizikalnog modela sa svim potrebnim elementima, 14 - skala za određivanje volumena vode $\mathrm{u}$ gornjem spremniku

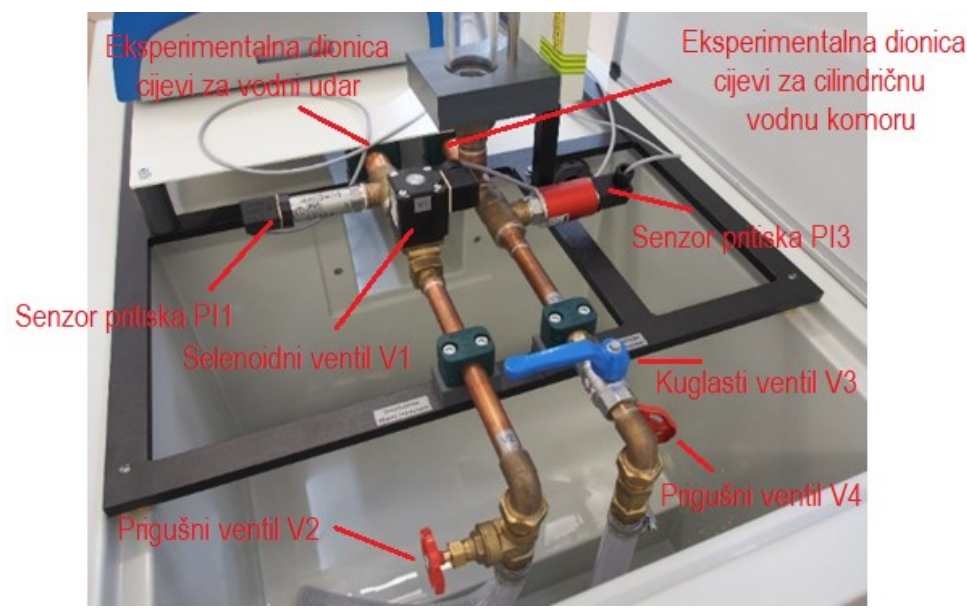

Slika 3. Ventili i senzori tlaka na fizikalnom modelu HM156 (Foto: Elvis Žic) 

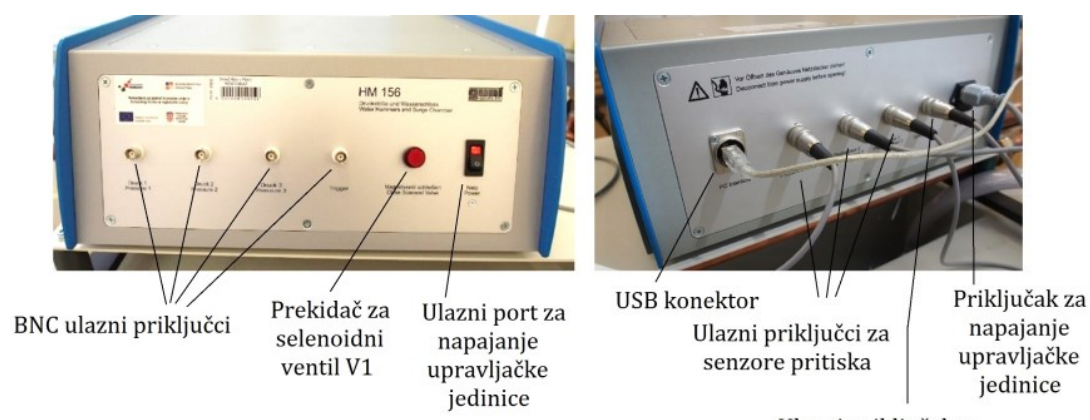

Ulazni priključak za selenoidni ventil V1

Slika 4. Prednja i stražnja strana upravljačke jedinice [Foto: Elvis Žic]

\subsection{Proračun osnovnih fizikalnih veličina}

Prema Laplaceu, brzina širenja male promjene tlaka $d p$ pod izentropskom kompresijom jednaka je:

$$
c=\sqrt{\frac{d p}{d \rho}}
$$

pri čemu je $c$ brzina zvuka [m/s], te $d \rho$ promjena gustoće vode $\left[\mathrm{kg} / \mathrm{m}^{3}\right]$. Brzina rasprostiranja tlačnog poremećaja u vodi pri $20^{\circ} \mathrm{C}$ iznosi $1483 \mathrm{~m} / \mathrm{s}$.

Za izračunavanje brzine zvuka $c$ potrebno je poznavati vrijednost perioda vala $t_{L}$. Period vala iskazuje trajanje jednog ciklusa periodične promjene, odnosno to je vrijeme u kojem harmonijska funkcija vala poprimi istu vrijednost. $U$ ovom slučaju se period vala $t_{L}$ može odrediti na temelju dobivenih vrijednosti promjena tlaka preko tlačnih senzora PI1 i PI2 koji su međusobno udaljeni $3 \mathrm{~m}$ (Slika 2). Ova vremenska vrijednost može se očitati iz softverskog sučelja na osciloskopu. Nakon poznate vrijednosti periode vala hidrauličkog udara $t_{L}$ određuje se brzina zvuka prema sljedećem izrazu:

$$
c=\frac{l}{t_{L}}
$$

pri čemu je $l$ uzeta kao valna dužina (kroz ispitivanja na fizikalnom modelu HM156 se ona uzima kao udaljenost između senzora pritiska PI1 i PI2 i iznosi $3 \mathrm{~m}$ što nije u potpunosti zadovoljavajuće). Periodi vala se iščitavaju iz računalnog programa namijenjenog HM 156 fizikalnom modelu kroz 2 ms. Periodi mogu varirati zbog elastične deformacije cijevi i neznatnih gubitaka trenja cijevi, tako da se vrijednost $1483 \mathrm{~m} / \mathrm{s}$ ne može točno postići $\mathrm{u}$ izračunima. U nastavku su dani izrazi za izračunavanje mase tijekom pojave vodnog udara u dovodnom cjevovodu $\left(m_{1}\right)$, mase u cilindričnoj vodnoj komori $\left(m_{2}\right)$, te prirast mase vode uslijed manevriranja zatvaračem ( $m$ ) (Slika 5.): 


$$
m_{1}=\frac{d^{2} \pi}{4} * L * \rho \quad m_{2}=\frac{D^{2} \pi}{4} * H * \rho \quad m=\frac{h * D^{2} * \pi * \rho}{4}
$$

dok su brzine u dolaznoj cijevi $\left(v_{1}\right)$ i cilindričnoj vodnoj komori $\left(v_{2}\right)$ definirane kao:

$$
v_{1}=\frac{D^{2}}{d^{2}} * v_{2} \quad v_{2}=\dot{h}
$$

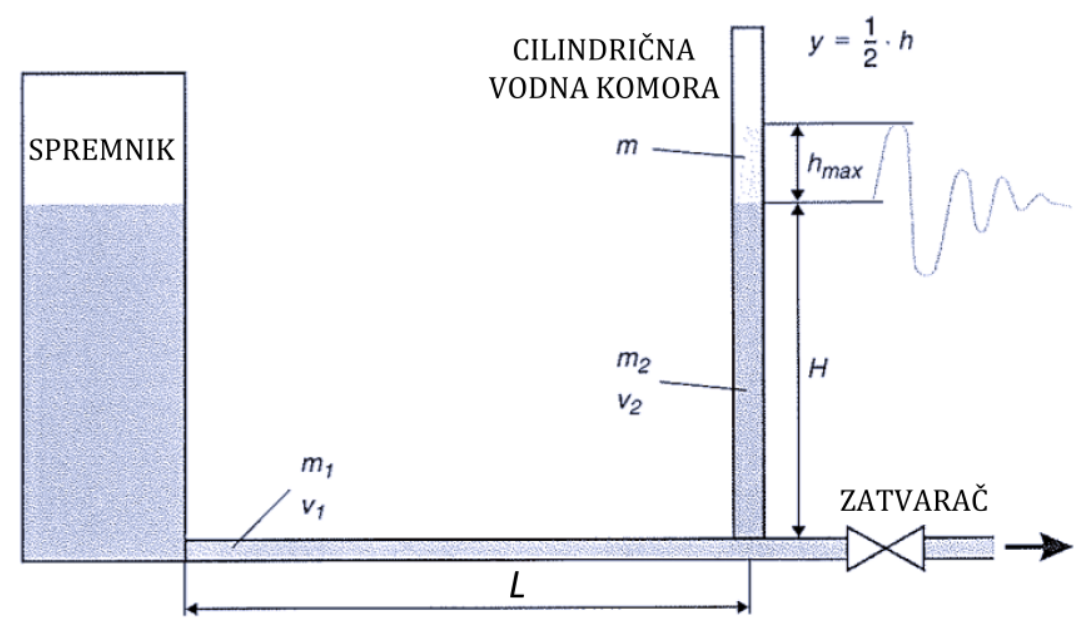

Slika 5. Veze između brzina širenja vodnih masa kod hidrauličkog udara [8]

Na temelju nadvišenja razine vode u vodnoj komori $h$ i izračuna brzina može se definirati ukupna potencijalna i kinetička energija u sustavu opisana diferencijalnom jednadžbom (23), $[1,8]$ :

$$
\begin{aligned}
& E_{\text {pot }}=m * g * y=\frac{h * D^{2} * \pi * \rho * g}{4} * \frac{h}{2}=\frac{D^{2} * \pi}{8} * \rho * g * h^{2} \\
& E_{k i n}=\frac{\pi * \rho}{8} *\left(d^{2} * L * \frac{D^{4}}{d^{4}} * \dot{h}^{2}+D^{2} * H * \dot{h}^{2}\right)
\end{aligned}
$$

iz koje se može dobiti izraz za određivanje prirodne frekvencije oscilacija cilindrične vodne komore pri pojavi hidrauličkog udara:

$$
f=\frac{\sqrt{\frac{g}{L *\left(\frac{D^{2}}{d^{2}}+H\right)}}}{2 * \pi}
$$

U izrazu (24) parametar $L$ predstavlja duljinu dovodne cijevi [m], $d$ promjer dovodne cijevi [m], $D$ promjer cilindrične vodne komore [m], dok je $H$ visina vode u cilindričnoj vodnoj komori [m]. Prirodna frekvencija oscilacija cilindrične vodne komore ne ovisi o protoku. Ova tvrdnja će se dokazati kroz provođenje eksperimenta u nastavku rada. 


\subsection{Primjeri provedenih pokusa}

Za potrebe ispitivanja oscilacija vodenih masa unutar cilindrične vodne komore provedeno je 5 pokusa (Tablica 1.). Unutar samih pokusa uzeto je više različitih vrijednosti razina vode u spremniku na temelju kojih su određene ostale fizikalne veličine. Suština ispitivanja bila je dobiti različite ovisnosti promjena prirodne frekvencije oscilacija vodne komore pri pojavi vodnog udara i pojedinih fizikalnih veličina iz Tablice 1 . Kao krajnji rezultat ispitivanja dobiveni su grafički prikazi iz kojih je sprovedena analiza ovisnosti pojedinih fizikalnih veličina (Slike 6.a-c).

Tablica 1. Rezultati ispitivanja [1], $d=2,6 \mathrm{~cm}$ - promjer dovodnog cjevovoda, $D=5,0$ cm - promjer vodne komore (V.K.), gustoća vode $\rho=998,0 \mathrm{~kg} / \mathrm{m}^{3}$

\begin{tabular}{|c|c|c|c|c|c|c|c|}
\hline 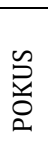 & $\begin{array}{l}\text { Razina } \\
\text { vode u } \\
\text { spremniku }\end{array}$ & $\begin{array}{l}\text { Razina vode u } \\
\text { cilindričnoj } \\
\text { V.K., } H\end{array}$ & $\begin{array}{l}\text { Maksimalna } \\
\text { razina } \\
\text { nadvišenja } \\
\text { vode u V.K. }\end{array}$ & $\begin{array}{c}\text { Protok, } \\
\quad Q\end{array}$ & $d^{2}$ & $D^{2}$ & $\begin{array}{l}\text { Duljina cijevi } \\
\text { između } \\
\text { spremnika i } \\
\text { vodne komore }\end{array}$ \\
\hline & $\mathrm{m}$ & $\mathrm{m}$ & $\mathrm{m}$ & $1 / \mathrm{s}$ & $10^{-3} \mathrm{~m}^{2}$ & $\mathrm{~m}^{2}$ & $\mathrm{~m}$ \\
\hline 1. & 0,485 & 0,280 & 0,290 & 0,225 & 0,676 & 0,0025 & 5,885 \\
\hline 2. & 0,470 & 0,240 & 0,270 & 0,225 & 0,676 & 0,0025 & 5,885 \\
\hline 3. & 0,450 & 0,200 & 0,260 & 0,225 & 0,676 & 0,0025 & 5,885 \\
\hline 4. & 0,510 & 0,350 & 0,310 & 0,225 & 0,676 & 0,0025 & 5,885 \\
\hline 5. & 0,530 & 0,390 & 0,340 & 0,225 & 0,676 & 0,0025 & 5,885 \\
\hline$\stackrel{n}{2}$ & $\begin{array}{l}\text { Masa vode } \\
\text { u cijevi, } m_{1}\end{array}$ & $\begin{array}{l}\text { Masa vode u v. } \\
\text { komori, } m_{2}\end{array}$ & $\begin{array}{l}\text { Masa vode u } \\
\text { nadvišenju, } m\end{array}$ & \multicolumn{2}{|c|}{$\begin{array}{l}\text { Potencijalna } \\
\text { energija, } E_{\text {pot }}\end{array}$} & $\begin{array}{c}\text { Kinetička } \\
\text { energija, } E_{\text {kin. }}\end{array}$ & $\begin{array}{c}\text { Prirodna } \\
\text { frekvencija, } f\end{array}$ \\
\hline L & $\mathrm{kg}$ & $\mathrm{kg}$ & $\mathrm{kg}$ & \multicolumn{2}{|c|}{$\mathrm{J}$} & $\mathrm{J}$ & $\mathrm{s}$ \\
\hline 1. & 3,12 & 0,95 & 0,57 & \multicolumn{2}{|c|}{0,808} & 1,832 & 0,258 \\
\hline 2. & 3,12 & 0,92 & 0,53 & \multicolumn{2}{|c|}{0,700} & 1,587 & 0,260 \\
\hline 3. & 3,12 & 0,88 & 0,51 & \multicolumn{2}{|c|}{0,649} & 1,471 & 0,261 \\
\hline 4. & 3,12 & 1,00 & 0,61 & \multicolumn{2}{|c|}{0,923} & 2,096 & 0,256 \\
\hline 5. & 3,12 & 1,04 & 0,67 & \multicolumn{2}{|c|}{1,111} & 2,524 & 0,255 \\
\hline
\end{tabular}

Na temelju dobivenih podataka sa Slike 6.a) može se zaključiti kako prirodna frekvencija oscilacija cilindrične vodne komore pri pojavi hidrauličkog udara ima različite vrijednosti za razinu vode u spremniku i razinu vode u cilindričnoj vodnoj komori, s napomenom da je ovisnost prirodne frekvencije i razine vode u spremniku gotovo linearna. Također, prirodna frekvencija nije ovisna o protoku koji je kroz dana ispitivanja predstavljao konstantnu vrijednost koju daje pumpa (Tablica 1.). Pri konstantnom protoku u sustavu dolazi do promjena brzina u dolaznoj cijevi i vodnoj komori ovisno o otvorenosti pojedinih ventila. Ovisno o povećanju mase vode u vodnoj komori i nadvišenju razine vode dolazi do opadanja prirodne frekvencije u sustavu (Slika 6.b). Iz Tablice 1. dobivena je ovisnost promjene prirodne frekvencije o kinetičkoj i potencijalnoj energiji (Slika 6.c) iz koje se može vidjeti da prirodna frekvencija u sustavu opada povećanjem kinetičke i potencijalne energije. Radi bolje ovisnosti pojedinih fizikalnih veličina autori rada predlažu veći broj pokusa. 

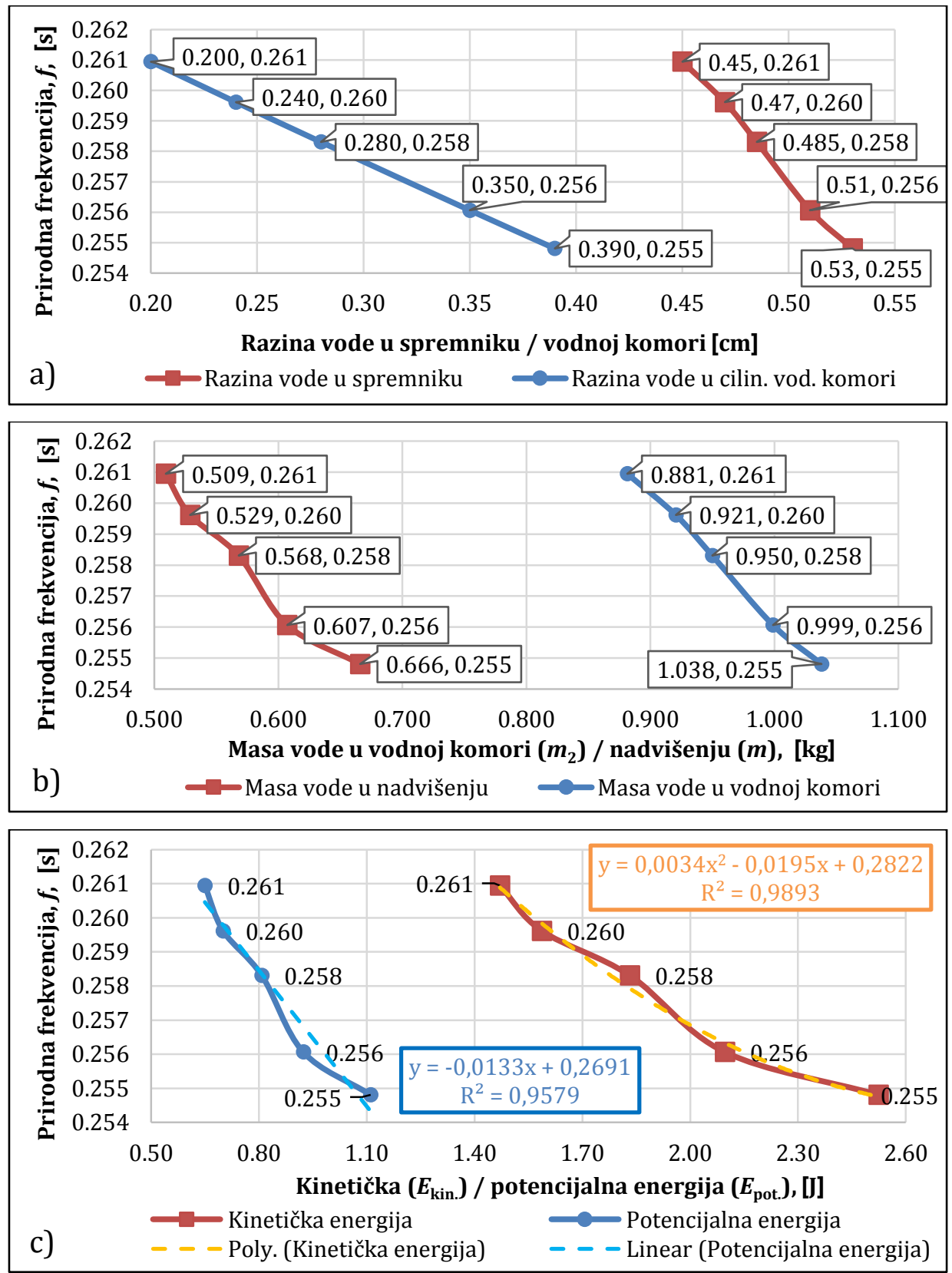

Slika 6. Prikaz ovisnosti pojedinih fizikalnih veličina: a) odnos prirodne frekvencije i razine vode u spremniku/vodnoj komori, b) odnos prirodne frekvencije i mase vode u spremniku/vodnoj komori, c) odnos prirodne frekvencije i kinetičke/potencijalne energije [1] 


\section{Teorijske osnove hidrauličkog udara}

Hidraulički udar predstavlja naglu promjenu tlaka u cijevi koji nastaje naglom promjenom brzine tekućine. Najčešća istraživanja se vrše na nagli prirast tlaka prilikom smanjenja brzine, npr. kada na kraju cjevovoda zatvorimo zasun (Slika 7.). Nastajanjem hidrauličkog udara u cijevi se pojavljuje zvuk koji podsjeća na zvuk udara čekićem o cijev te iz toga i proizlazi engleski naziv „Water hammer" [5]. Pojava hidrauličkog udara je blaža što su cijevi kraće, a rasprostiranje u dovodni tunel se smanjuje pomoću vodnih komora koje osiguravaju vodu u slučaju promjene protoka u tlačnim cjevovodima [2,7]. Hidraulički udar pripada skupini strujanja pod tlakom izrazito nestacionarnog karaktera kod kojih treba uzeti u obzir lokalno ubrzanje, stišljivost vode i elastičnost cjevovoda.

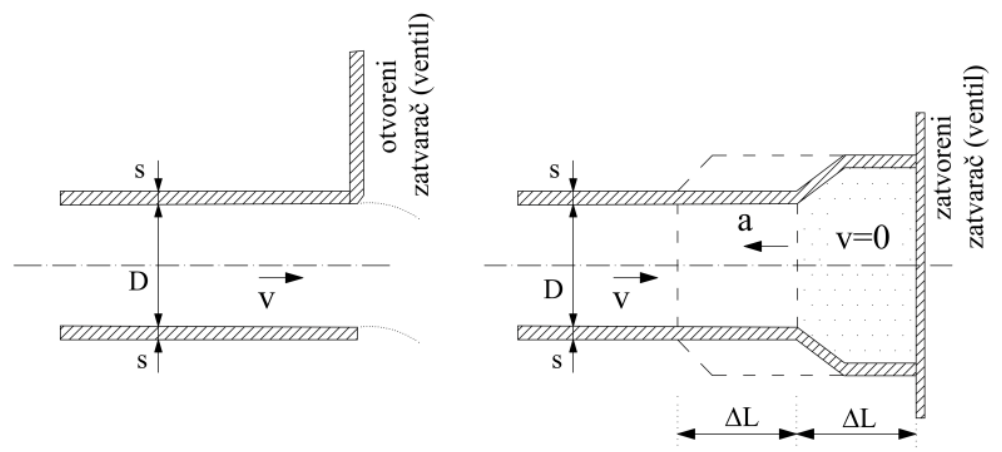

Slika 7. Pojava i širenje hidrauličkog udara [7]

Pri definiranju jednadžbi hidrauličkog udara usvajaju se naredne pretpostavke [3, 4]: 1) promjena volumena koja nastaje zbog hidrauličkog udara, tj. povećanja tlaka je malena u odnosu na početni volumen, 2) promjene brzine su nagle te 3 ) brzina strujanja $v$ se zanemaruje u odnosu na brzinu udarnog vala $a$. Kad voda ne bi bila stlačiva (kompresibilna), pri naglom zaustavljanju sva voda duž tlačnog cjevovoda bi se prestala kretati. Budući da je voda stlačiva, a cjevovod elastičan, voda se sabija a cjevovod rasteže na dionici $\Delta L$ na kojoj je došlo do zaustavljanja toka zbog kinetičke energije [7, 8]. Promjene gustoće vode koje se događaju prilikom hidrauličkog udara su malene te ne utječu bitno na točnost proračuna. Jednadžba brzine širenja hidrauličkog udara zasniva se na izražavanju relativne promjene gustoće preko elastičnih svojstava vode $\left(E_{v}\right.$ i $E_{c}$ su moduli elastičnosti vode i cijevi), dok su relativne promjene volumena i gustoće $\rho$ povezane kroz uvjet konstantnosti mase unutar volumena:

$$
a=\frac{\sqrt{\frac{E_{v}}{\rho}}}{\sqrt{1+\frac{E_{v} D}{E_{C} S}}}
$$


U izrazu (25) simbol $D$ predstavlja promjer tlačnog cjevovoda, dok je $s$ debljina stijenke tlačnog cjevovoda. U slučaju krutog cjevovoda brzina širenja hidrauličkog udara je $a=\sqrt{\frac{E_{v}}{\rho}}$. Za uobičajene dnevne temperature ova brzina iznosi $a=1425 \mathrm{~m} / \mathrm{s}$.

\subsection{Primjena fizikalnog modela i primjeri provedenih pokusa}

Hidraulički udar se javlja kod zatvaranja ventila V1. Senzori tlaka PI1 i PI2 mjere rezultirajuće oscilacije tlaka (Slika 8.a)). Za uspješno provođenje ovog pokusa potrebno je sprovesti nekoliko koraka koji su detaljno opisani u radu [1]. Nakon odrađene pripremne faze kreće se sa provođenjem pokusa na način da se odabire u programskom sučelju „Analiza hidrauličkog udara" ("Water hammer") nakon kojeg se pokrene opcija "Start". Solenoidni ventil V1 se zatvara i uzrokuje hidraulički udar. Istodobno, senzori tlaka PI1 i PI2 počinju mjeriti pritiske. Mjerenje završava nakon 0,03 s. Računalni program prikazuje tlakove mjerene na senzorima tlaka PI1 i PI2 tijekom vremena. Pomoću dva pokazivača (žuto označene linije) određuje se „modificirani“ period vala hidrauličkog udara između tlačnih senzora PI1 i PI2 (Slika 8.a) te, posljedično, brzina zvuka u danom cijevnom sustavu.

Cilj ovih pokusa je dobivanje oscilacija vodnih masa u cilindričnoj vodnoj komori (Slika 8.b). Kuglasti ventil V3 u izlaznoj komori je zatvoren, čime se stvara hidraulički udar koji se nastoji smanjiti pomoću vodne cilindrične komore, a senzor tlaka PI3 mjeri rezultirajuće oscilacije tlaka. Nakon odrađene pripremne faze koja je detaljno opisana u radu [1], odabere se u programskom sučelju „Analiza oscilacija vodnih masa“ (eng. „Surge chamber"). Provode se sljedeći koraci u brzome slijedu: aktiviranje opcije „Start" na grafičkom sučelju, brzo zatvaranje kuglastog ventila V3 u potpunosti te brzo isključivanje pumpe. Zatvaranjem kuglastog ventila V3 inicira se pojava hidrauličkog udara. Tlak se mjeri na senzoru tlaka PI3. Mjerenje završava nakon 60 sekundi kada se više ne očituju oscilacije vodnih masa u vodnoj komori. Pokretanje vala može se promatrati kao oscilacija razine vode u cilindričnoj vodnoj komori preko osciloskopa ili preko fotoaparata, odnosno video zapisa koji detektira cjelokupni proces.

U Tablici 2. su prikazani rezultati ispitivanja pojave hidrauličkog udara na fizikalnom modelu HM156. Tijekom samog ispitivanja provedeno je 10 pokusa pri temperaturi vode od $18^{\circ} \mathrm{C}$. Unutar svakog pokusa uzeti su različiti podaci razina vode u spremniku i cilindričnoj vodnoj komori (Tablica 2.). Manja odstupanja u vrijednostima protoka kroz pojedine pokuse posljedica su volumetrijskog načina njegova određivanja (u suštini, cirkulacijski protok u sustavu bi trebao biti konstantan - rad pumpe). 

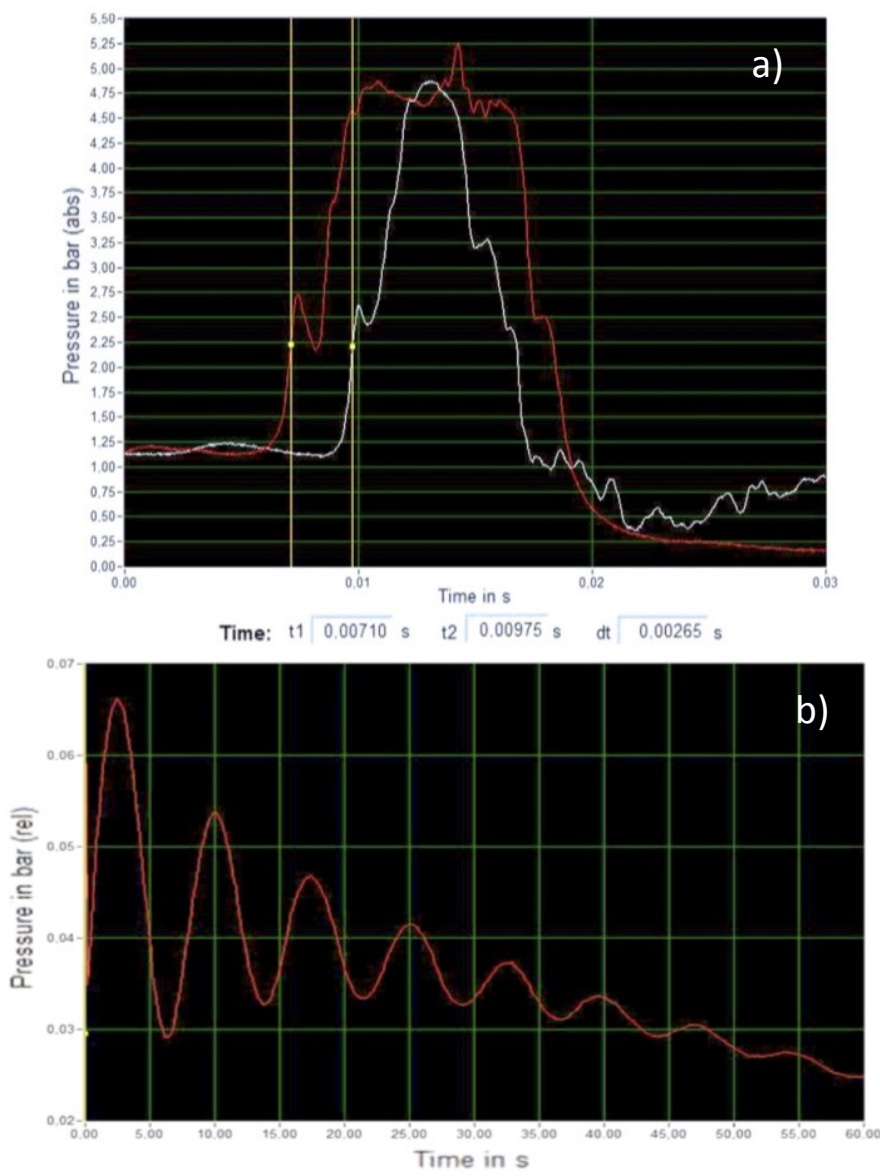

Slika 8. Primjena fizikalnog modela kod a) analize hidrauličkog udara, b) oscilacija vodnih masa u cilindričnoj vodnoj komori [1]

Tablica 2. Rezultati ispitivanja [1] $t_{1}, t_{2}-$ vremenski indikatori za pojavu nadvišenja tlaka na senzorima tlaka PI1 i PI2

\begin{tabular}{|c|c|c|c|c|c|c|c|c|}
\hline \multirow[t]{2}{*}{$\begin{array}{l}\mathscr{c} \\
\stackrel{2}{O}\end{array}$} & $\begin{array}{c}\text { Razina } \\
\text { vode u } \\
\text { spremniku }\end{array}$ & $\begin{array}{c}\text { Razina vode } \\
\text { u cilindr. } \\
\text { vodnoj } \\
\text { komori }\end{array}$ & $\begin{array}{c}\text { Protok, } \\
Q\end{array}$ & $t_{1}$ & $t_{2}$ & $t_{L}=t_{2}-t_{1}$ & $l$ & $\begin{array}{c}\text { Brzina } \\
\text { zvuka, } c\end{array}$ \\
\hline & M & $\mathrm{m}$ & $1 / \mathrm{s}$ & $\mathrm{s}$ & $\mathrm{s}$ & $\mathrm{s}$ & $\mathrm{m}$ & $\mathrm{m} / \mathrm{s}$ \\
\hline 1. & 0,805 & 0,630 & 0,188 & 0,00220 & 0,00420 & 0,00200 & 3,0 & 1500,0 \\
\hline 2. & 0,600 & 0,430 & 0,164 & 0,00235 & 0,00436 & 0,00201 & 3,0 & 1492,5 \\
\hline 3. & 0,695 & 0,530 & 0,222 & 0,00231 & 0,00432 & 0,00201 & 3,0 & 1492,5 \\
\hline 4. & 0,730 & 0,560 & 0,200 & 0,00235 & 0,00437 & 0,00202 & 3,0 & 1485,1 \\
\hline 5. & 0,450 & 0,280 & 0,172 & 0,00229 & 0,00429 & 0,00200 & 3,0 & 1498,5 \\
\hline 6. & 0,530 & 0,360 & 0,178 & 0,00245 & 0,00444 & 0,00199 & 3,0 & 1507,5 \\
\hline 7. & 0,400 & 0,230 & 0,149 & 0,00235 & 0,00436 & 0,00201 & 3,0 & 1492,5 \\
\hline 8. & 0,190 & 0,020 & 0,136 & 0,00232 & 0,00433 & 0,00201 & 3,0 & 1491,8 \\
\hline 9. & 0,100 & 0,012 & 0,125 & 0,00224 & 0,00424 & 0,00200 & 3,0 & 1499,3 \\
\hline 10. & 0,335 & 0,160 & 0,135 & 0,00235 & 0,00437 & 0,00202 & 3,0 & 1485,1 \\
\hline
\end{tabular}


Kao krajnji rezultat ispitivanja dobiveni se grafički prikazi iz kojih se mogu definirati razne ovisnosti pojedinih fizikalnih veličina (Slike 9.a-c).
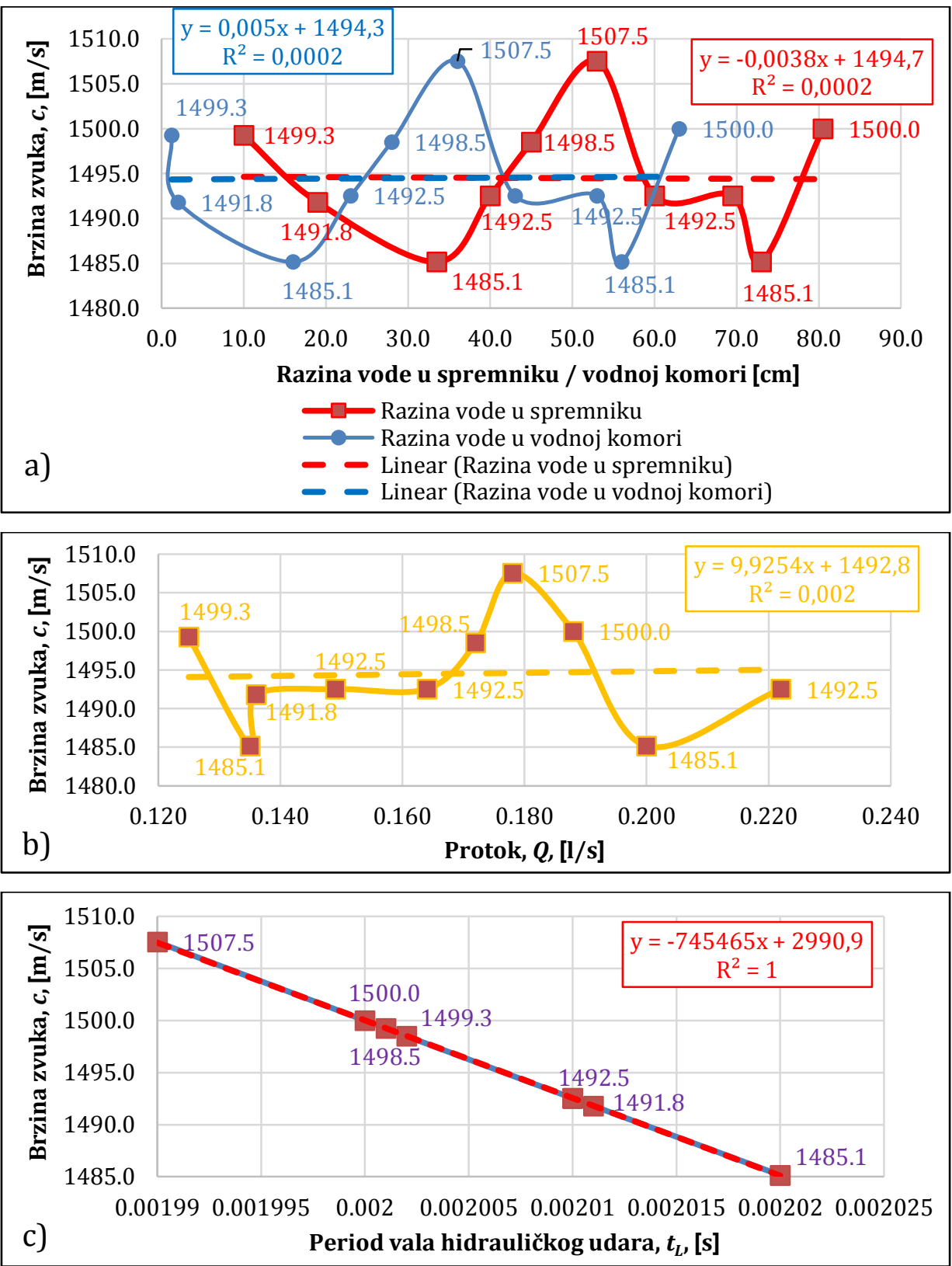

Slika 9. Prikaz ovisnosti fizikalnih veličina: a) odnos brzine širenja zvuka i razine vode u spremniku/vodnoj komori b) odnos brzine širenja zvuka i protoka, c) odnos brzine zvuka i perioda vala hidrauličkog udara, [1] 
Analizom podataka sa Slike 9.a) može se vidjeti kako brzina širenja zvuka u vodi ima približno jednake vrijednosti za različite razine vode u spremniku i cilindričnoj vodnoj komori pa se prema tome može zaključiti kako brzina širenja zvuka ne ovisi o navedenim razinama. Treba naglasiti kako su dobivene vrijednosti brzina širenja zvuka u tlačnoj cijevi nešto veće od standardne vrijednosti u iznosu od $1483 \mathrm{~m} / \mathrm{s}$. Razlog tomu su manja odstupanja očitanja vremenskih indikatora $t_{1}$ i $t_{2}$ na grafičkom prikazu za pojavu nadvišenja tlaka na senzorima tlaka PI1 i PI2. Vrlo mala odstupanja tih vrijednosti rezultiraju značajnijim promjenama brzina širenja zvuka pa $\mathrm{u}$ tom segmentu mjeritelj/ispitivač treba biti jako oprezan tijekom ispitivanja. Promjene brzine zvuka se neznatno mijenjaju uslijed promjene razine vode u vodnoj komori (u rasponu od 61,8 cm) u granicama od 1485,1 do $1507,5 \mathrm{~m} / \mathrm{s}$ (Slika 9.a). Uslijed manjih odstupanja vrijednosti protoka u dovodnom cjevovodu (zbog volumetrijskog određivanja) vrijednost brzine zvuka se neznatno mijenja (Slika 9.b). U suštini, brzina zvuka je neovisna o protoku koji struji kroz cijevni sustav. U stvarnosti, brzina zvuka nije ovisna o brzini medija u kojem se zvuk propagira pa se još jednom napominje kako je do manjih odstupanja došlo isključivo zbog otežanog očitanja pojedinih fizikalnih veličina (prvenstveno izračuna vremenskih indikatora $t_{1}$ i $t_{2}$ ). Analizom podataka sa Slike 9.c) može se zaključiti kako brzina širenja zvuka ima linearnu ovisnost (koeficijent korelacije $R^{2}=1$ ) kod različitih vrijednosti perioda vala hidrauličkog udara te će brzina širenja zvuka biti veća kod manjih vrijednosti perioda vala hidrauličkog udara.

\section{Zaključak}

U ovom radu su dokumentirana istraživanja provedena na fizikalnom modelu HM156 vezana za oscilacije vodnih masa i hidrauličkog udara u sustavima pod tlakom. Hidraulička analiza je pokazala da u dovodnom cjevovodu nema značajnih odstupanja u vidu promjene brzine širenja zvuka uslijed različitih vrijednosti razina vode u spremniku i cilindričnoj vodnoj komori. Iz jednadžbe oscilacije vodne mase u sustavu akumulacija - dovodni cjevovod - vodna komora pri naglom zatvaranju zasuna može se odrediti maksimalni porast i pad razine vode u cilindričnoj vodnoj komori. Rješenje pokazuje da su oscilacije u obliku sinusne funkcije s periodom osciliranja ovisnim o geometriji dovodnog cjevovoda i vodne komore te amplitudom ovisnom o početnoj brzini vode u dovodnom cjevovodu i početnoj razini vode u cilindričnoj vodnoj komori prije zatvaranja zasuna. Zbog nagle promjene tlaka koja se dešava prilikom naglog zatvaranja zasuna, u tlačnoj cijevi nastaje hidraulički udar koji se rasprostire brzinom zvuka u tlačnoj cijevi. Kroz primjenu fizikalnog modela dokazano je da prirodna frekvencija oscilacija vodne cilindrične komore pri pojavi hidrauličkog udara ne ovisi o protoku. Bitno je za napomenuti da se cilindrična vodna komora na 
fizikalnom modelu HM156 može zamijeniti sa bilo kojim drugim tipom vodne komore (preko osnovnog navoja) koja bi se tom prilikom izradila na 3D printeru u sklopu hidrotehničkog laboratorija. Time bi se analizirali i drugi slučajevi oscilacija vodne mase u različitim asimetričnim vodnim komorama kod kojih je poprečni presjek funkcija razine vode u vodnoj komori.

Zahvala. Ovaj je članak rezultat rada u okviru projekta Razvoj istraživačke infrastrukture na Kampusu Sveučilišta u Rijeci (RC.2.2.06-0001), koji je sufinanciran iz Europskog fonda za regionalni razvoj (EFRR) $i$ Ministarstva znanosti, obrazovanja i sporta Republike Hrvatske.

\section{Literatura}

[1] Brenko, M. (2018) Oscilacije vodnih masa u sustavu pod tlakom, završni rad iz kolegija Hidromehanika, Građevinski fakultet Rijeka, Rijeka.

[2] Travaš, V. (2014) Oscilacije vodnih masa u vodnoj komori generičkog oblika, Građevinar, 66, 4, str. 323-334, DOI: 10.14256/JCE.989.2013

[3] Gjetvaj, G. (2009) Hidraulika - sistemi pod tlakom, interna skripta iz kolegija Hidraulika, Građevinski fakultet Zagreb, Zagreb.

[4] Žic, E., Ožanić, N., Karleuša, B. (2012) Mehanika fluida - teoretske osnove s riješenim zadacima, Skripta zadataka iz kolegija Hidromehanika, Građevinski fakultet Sveučilišta u Rijeci, Rijeka.

[5] Shaughnessy, E.J., Katz, I.M., Schaffer, J.P. (2005) Introduction to Fluid Mechanics, Oxford University, Oxford.

[6] Stojić, P. (1999) Hidrotehničke građevine - knjiga III, Građevinski fakultet Sveučilišta u Splitu, Split.

[7] Agroskin, I.I. (1969) Hidraulika, Tehnička knjiga, Zagreb.

[8] Gunt Hamburg. (08/2014) Water Hammers and Surge Chamber - Experiment Instructions, priručnik za rad s fizikalnim modelom HM 156, Hamburg.

[9] Bukurov, M., Žic, E. (2017) Mehanika fluida - teoretske osnove, radni priručnik za potrebe studenata na kolegiju Mehanika fluida i Hidromehanika, Građevinski fakultet Sveučilišta u Rijeci, Rijeka. 